\title{
AN ARAB PERSPECTIVE ON SOCIAL MEDIA: HOW BANKS IN KUWAIT USE INSTAGRAM FOR PUBLIC RELATIONS
}

\author{
Ali A. Al-Kandari \\ Associate Professor of Mass Communication at Gulf University for Science and Technology \\ Gulf University for Science and Technology \\ P.O. Box 7207 \\ Hawally 32093 \\ Kuwait \\ Email: alkandari.j@gust.edu.kw \\ Tel.: +965-2530-7475 \\ T. Kenn Gaither \\ Associate dean/professor at the Elon University School of Communications \\ 100 Campus Drive \\ 2850 Campus Box \\ Elon, NC 27244 \\ tgaither@elon.edu \\ (336) 278-5776 \\ Mohamed Mubarak Alfahad \\ Senior Coordinator of Public Relations in the Kuwaiti Ministry of Defense \\ Email: mohalfahad1988@gmail.com \\ Tel.: +965-5669-9955 \\ Ali A. Dashti \\ Associate Professor of Mass Communication at Gulf University for Science and Technology, \\ Gulf University for Science and Technology \\ P.O. Box 7207 \\ Hawally 32093 \\ Kuwait \\ Email: dashti.a@gust.edu.kw \\ Tel.: +965-2530-7089
}

\section{Ahmed R. Alsaber}

Ph.D. candidate, mathematical statistics at the University of Strathclyde, UK.

Email: a.alsaber@strath.ac.uk

Tel.+965-9770-3330 


\title{
AN ARAB PERSPECTIVE ON SOCIAL MEDIA: HOW BANKS IN KUWAIT USE INSTAGRAM FOR PUBLIC RELATIONS
}

\begin{abstract}
This study examines the public relations functions of eight Kuwaiti banks listed in the Kuwait Stock Exchange Market (KSEM) that post on their Instagram accounts. It also uses market-size, organization, and individual level predictors to model Instagram postings. A content analysis of 1,502 posts revealed the banks use Instagram for promotion, information dissemination, community building, and interactive engagement, in that order of prominence. The findings suggest banks operate at the confluence of visual communication through Instagram and integration of religious symbolism to serve a public relations function predicated on image and influence. In doing so, the banks tap into the wellspring of social media use by target publics by navigating a balance between obedience to Allah and meeting bank business objectives. The resulting tension between sacred and secular highlights Arab cultural values and suggests Instagram fosters individualism, which challenges Arab emphasis on collectivism and fractures the notion online platforms can effectively build meaningful relationships that characterize Arab culture. The study posits Instagram is more effective in an Arab context at image building than relationship building, threading the importance of visual communication through social media across Arab culture and global public relations practices.
\end{abstract}


A Middle Eastern country, the State of Kuwait is bordered by Iraq on the North, Saudi Arabia on the South and the Arabian Gulf on the East. The population of the country is estimated to be roughly 4 million, of which Kuwaiti nationals represent only $31 \%$. The country is a constitutional monarchy in which the Emir shares authority with an elected national assembly. Oil is the main contributor to the country's economy (CIA Factbook, 2017). Kuwait enjoys a robust banking system due to the supportive policy of the Kuwaiti Central Bank, a healthy economy and limited competition from foreign banks. Nearly $80 \%$ of the population has Internet access, providing the technological underpinnings for what Greenfield (2013) calls "Kuwait's booming Instagram economy." More than 40 percent of the Kuwaiti population uses Instagram (Statista, 2016). Kuwait is not alone; according to Brandwatch (2019), the number of monthly active Instagram users is more than one billion globally. Instagram is now one of the most popular social networks worldwide, especially among those 35 and under (Statista, 2018). Despite the meteoric rise in Instagram use, little research has examined its implications for global public relations practice, and no extant studies have focused on its prominence and use for public relations in the Arab world, where culture and religion are inextricably linked.

There is a general consensus in the literature that certain attributes and practices characterize Arab public relations. Many studies use the centrality of Islam as a focal point that distinguishes public relations in the Middle East from its western counterparts. Islam is, to varying degrees, so pervasive that it is arguably indistinguishable from culture (Al-Kandari \& Gaither, 2011). The influence of Islam on public relations creates a dialectic where “... An Islamic model of public relations would be [a] community-oriented model in which publics and organizations are not viewed as two opposing elements but rather two components of the same community" (Ayish \& Awad, 1994, p. 100). Despite Kruckeberg's (1996) contention that 
"sophisticated" public relations is being practiced in the Middle East, its efficacy is challenged by administrators who do not fully grasp its value and function. According to Kirat (2005), many in senior management have negative attitudes toward the profession and Arab public relations practitioners perform asymmetrical modes of public relations. Practitioners mainly perform technical roles and often lack proper knowledge, training and resources that would permit them to perform progressive public relations responsibilities. Arab senior management view public relations as a place for "those with no jobs" (Al-Tarah, 1995). Instead of adopting progressive public relations strategies, senior management believe they can achieve organizational objectives using the personal influence model (Sriramesh, 1996) by establishing strong social ties with influential members in society and doing them favors. As a result, the roles of practitioners are limited to the technical realm, consisting of protocol, hospitality and ceremonial functions. In government agencies, practitioners receive and accompany foreign diplomats, and organize events and conferences (Ayish \& Kruckeberg, 1999).

Kirat (2005) argues that Arab practitioners cannot embrace two-way symmetrical communication because it requires a culture and political system promoting democracy and civic engagement. Such requirements are at odds with the dominant communication and organizational culture in Arab organizations that foster hierarchical work settings and practices. Badran and Ayish (1996) argue the Arab patriarchal work structure stresses public relations models of press agency and information dissemination. Al-Enad (1990) describes the prevalent Arab model of public relations as propaganda aimed at influencing the public. Other obstacles include limitations set by senior management on practitioners who rarely participate in decisionmaking processes because senior management has a limited understanding of the profession, its nature, objectives, and roles. Public relations departments are usually placed in an organizational 
chart that excludes practitioners from direct access to senior management. There is a lack of proper managerial ability to conduct research and strategic long- term planning (Kirat, 2006).

Change is slowly occurring. According to Kirat (2005), many economic, tourism and industrial sectors are expanding and facing increased pressure to elevate public relations practices. In response to a global, capital and open market, practitioners must stay abreast of information technology and increasingly sophisticated customers, particularly in the Arab Gulfoil area, where Kuwait is located. The Arab Spring sparked a demand for greater transparency to the public and far more sensitivity to public opinion. In turn, Arab nations have designated communications representatives to participate in meetings and to address the public and press. And after decades of forced Arab government media, Arab citizens now are turning to social media as a conduit for free expression of opinion. In response, Arab corporations have established a social media presence to meet the demands of the public, update them with information, and respond to queries.

Research examining the use of social media for public relations purposes in the United States has mainly focused on Facebook (e.g. Cho et al., 2014; Lee et al., 2014; Saxton \& Waters, 2014) and Twitter (e.g. Adams \& McCorkindale, 2013; Einwiller \& Steilen, 2015; Saffer et al., 2013). This focus is justifiable given that the majority of Americans prefer Facebook. Until 2013, Twitter was the third most preferred social medium after Facebook and LinkedIn (Pew Social Media Report, 2016). American companies employ Facebook and Twitter for public relations because they are considered more "mature" social media (Barnes et al., 2012). Public relations practitioners consider Facebook, LinkedIn and Twitter the best social media to serve organizational objectives (Wright \& Hinson, 2013). However, in Kuwait, Instagram is the most favored social medium, followed by Snapchat and Twitter (Greenfield, 2013; Kamal, 2016). 
Therefore, having a sizable public on Instagram can influence Kuwaiti corporations' choice of medium for public relations.

Recent data reveal that Instagram is rapidly increasing in popularity. A recent Pew Social Media Report (2018) shows that 68\% of American social media users favor Facebook, followed by Instagram (35\%), Pinterest (29\%), Snapchat (27\%), and Twitter (24\%). Another 2015 Pew study found Instagram is the fastest growing social medium, doubling in size since 2012. Conner (2016) reports the findings of surveys conducted on visual culture and communications by the Pew Research Center, Nielsen Group and other entities. The findings reveal that $63 \%$ of people prefer visual demonstrations over text instructions to learn specific processes and ideas. The timespan of human attention, approximately eight seconds, is well suited to visual communication; visual messages are processed 60,000 times faster than text (Conner, 2016). Social media communications that consist of visuals generate more interaction; tweets with images receive $18 \%$ more clicks, $89 \%$ more favorites, and $150 \%$ more retweets (Conner, 2016). Visual and audio contents add emotion to facts. Even so, there has been little research linking public relations to visually-oriented social media, visual communication content and visual culture. This study answers the call posed by Pressgrove, Janoske, \& Haught (2018), who lamented the paucity of resources in visual communication occupying the space between public relations practice and scholarship and called for further research to "...dive deeper into the use of visuals in myriad contexts (p. 319)".

As a visually intensive social medium, Instagram can be used to post photos, images and videos to support brand perceptions. Disseminating information and ideas with visual cues enhances message recognition, comprehension, and recall, with residual effects (Al-Kandari, Melkote, \& Sharif, 2016). The visual nature of Instagram appeals to ages 18-29, who comprise 
59\% of its users (Pew, 2015), making it appropriate to target young people to establish brand preferences and engender loyalty (Allaguia \& Breslowba, 2016). Corporations can also use Instagram to maintain relationships with key publics through images concerning community interests and social responsibility. Furthermore, Instagram followers can directly and publicly provide feedback and opinions to organizations about their services, products and performance (Bergström \& Bäckman, 2013). The comment function on Instagram allows users to create a narrative around and about images without necessarily engaging in dialogue with the host organization. Previous research has employed content-centered approaches to analyze message characteristics of public relations functions that social media serve. Few researchers have examined the factors that predict posting activities on social media. Research in business administration (Hackler \& Saxton, 2007; Nah \& Saxton, 2012) suggest that market-level factors such as market size and profitability predict information disclosure on the Internet. Other studies establish that organizational and individual level factors predict the adoption of technology and new media in general and for public relations purposes (Al-Shohaib et al., 2009; Moreno et al., 2015; Ruck \& Welch, 2012).

This study uses a content analysis to identify the public relations functions for Kuwaiti banks using Instagram. It also examines the impact of three sets of predictors on the Instagram posting activities of banks. Market-level predictors relate to size of banks (market value, rate of bank's shares on the stock market, number of branches, and number of Instagram followers), organizational-level predictors include the number of employees, and levels of support and encouragement received by public relations and communication practitioners and departments from senior managements, and individual-level predictors encompass perceptions of practitioners and senior managements about the power of social media and Instagram to achieve public 
relations objectives, and the perceptions of practitioners of Instagram's ability to achieve the objectives better than other social media. Most research that links social media to public relations reflects a Western context and profile. Employing the Kuwaiti context in this study deepens the understanding of social media use for public relations purposes and the predictors of adoption in non-Western countries. Finally, it can illuminate the effectiveness of the visual emphasis of Instagram as a public relations platform across cultures and nations through an Arab lens.

\section{Literature Review}

\section{Instagram use for public relations functions by banks in Kuwait}

At the incipient phase of the Internet, scholars expressed enthusiasm about its online dialogic features (Wright \& Hinson, 2013). To theorize online media, many have particularly embraced the dialogic relationship management model of Kent and Taylor and the symmetric, two-way model of public relations of Hunt and Grunig (Waters \& Jamal, 2011). These models offer a normative approach to the way practitioners can use new media to provide ethical and two-way symmetrical communication (Kent \& Tylor, 1998). However, research demonstrates that the use of online media by corporations generally repeats the practices of information dissemination and opinion manipulation that are applied in offline settings (e.g. Cho et al., 2014; Weberling et al., 2012). Two views have emerged to explain this finding. One is familiarity with asymmetrical paradigms, deficiencies of expertise and training in online contexts. Following this vein, the lack of readiness to adapt to a new online environment has caused practitioners to abandon online symmetrical communications with publics (Wright \& Hinson, 2008; Waters \& Jamal, 2011). The other view argues that publics are still ill-equipped and unready to use symmetrical online features. Weberling et al. (2012) argue that only active publics want to engage in dialogic online communication. To better reach disengaged publics, Breakenridge 
(2012) calls for more strategic and tactical messages to connect with users. Kelleher (2009) advises that grounding interactive communications in commitment, trust and honesty can encourage inactive publics.

Kent et al., (2003) and Saxton et al. (2007) found organizations rarely employ online platforms to engage stakeholders. Greenberg and MacAulay (2009) suggest the majority of Canadian environmental organizations employ information dissemination functions on social media and few experiment with dialogic features. Other research echoes this trend and confirms that organizations mainly employ Facebook for information dissemination (Wright \& Hinson, 2011) and social media to convey persuasive messages (Valentini, 2015). Organizations have failed to open a dialogue with stakeholders on Facebook (Waters et al., 2009) and mainly engage clients by recycling previous online inquiries (McCorkindale, 2010). Other scholars have turned to Twitter, which they view as a message-response format that can foster dialogic exchange, unlike billboards or noticeboards. Lovejoy et al., (2012) indicate that $64 \%$ of tweets consist of one-way communication messages, $20 \%$ employ conversation features, and $16 \%$ indirect communications with specific users. Similar outcomes led McCorkindale (2012) to suggest that few organizations have acted to engage in dialogic practices with clients on Twitter. Until 2009, the use of Twitter was predominantly limited to one-way communication. Other scholars are optimistic and contend that time will eventually produce an organizational tendency, propelled by consumer demand and preferences, to engage in online symmetrical communications (Alikilic \& Atbek, 2012). To show that online practices have changed over time, Wright and Hinson (2011) argued Facebook was used mainly for marketing until 2009 before transitioning to public relations in 2010 . 
In sum, research indicates online media have been used for four main functions: publicity and information dissemination; social responsibility and community building; promotion and marketing; and engagement and dialogue (Valentini, 2015). Lovejoy and Saxton (2012) found that the 100 biggest American non-profit organizations have mainly employed Twitter for information (59\% of tweets), then community building (21\%), promotion and marketing (16\%), and last, dialogue (4\%). In Malaysia, Parveen et al. (2015) found that organizations employed social media for advertising and promotion, followed by branding, information dissemination, and dialogue.

This paper suggests banks in Kuwait are likely to use Instagram for similar functions to those found in the West and other nations because of the visual orientation of Instagram. Moreover, it posits Kuwaiti banks will employ it mainly for a one-way asymmetrical communication rather than for engagement and dialogue for two reasons. From a mediadeterministic approach, the image-video nature of Instagram makes it a personality-oriented medium that appeals to emotions and accordingly is effective for image building, identity construction, and self-presentation (Al-Kandari et al., 2016). Jackson (2015a; 2015b) found Instagram has the most engaged users of any social medium due to its visual nature and absence of "noise," including advertisements and links. Visual dominance can reflect activities of social responsibility and community building that users view and recall quicker than written social media. Second, Arab public relations practices foster asymmetrical communication in public relations (Kirat, 2006). The over-centralized managerial characteristics of Arab organizations nurture a patriarchal and autocratic style (Scarborough, 2000) that discourage progressive, innovative and symmetrical public relations (Al-Tarah, 1995). Authoritarianism and strict complex hierarchy will limit two-way symmetrical communications in social media, which rely 
on interactivity and spontaneity embedded in a free style and autonomy. Quick responses to online messages and interactivity do not fit with autocratic bureaucratic styles that require preapproval from senior management. Arab top-down authoritarian management styles do not recognize or value public feedback, so Instagram is likely to be restricted to asymmetrical posts (Badran, 1994).

\section{Predictors of Instagram posting activities}

\section{Market-level factors}

Nah and Saxton (2012) suggest theories of technology adoption such as diffusion of innovations and the technology acceptance model are limited to predicting adoption at an individual level. They argue macro-level theories are needed to generate a broader understanding of the external variables that drive technology use at an organizational level. Ultimately, decisions about technology adoption in an organization are generally left to top management, which decide adoption based on market, competition and organizational needs. According to Nah and Saxton, the resources available to an organization can forecast its adoption of online networking. The size of the organization, including its financial capabilities and assets, affect the networking and technical staff that maintains it. Hackler and Saxton (2007) found that budgetary limitations hindered adoption of technologies. When an organization grows, it receives more public attention and scrutiny requiring a greater online presence. Debreceny et al. (2003) found that size of organization, current intangible assets, and future growth opportunities were associated with online presence. Craven and Marston (1999) suggested turnover, number of employees, total assets, and value of the organization in the market predicted online information disclosure and level of website richness. Oyelere et al. (2003) reported that organizational liquidity and market capitalization predicted the frequency of information dissemination. 
This study anticipates a relationship between the market size of banks (market value, rate shares in the stock market, number of branches, and number of followers) and Instagram posting activities. While number of Instagram followers and bank branches do not necessarily reflect the number of bank account holders, they do indicate size. Having more Instagram followers and more branches may be related to the volume of bank account holders. This can denote the importance of increasing online presence and posting activities on Instagram.

\section{Organization-level factors}

\section{Number of employees}

DiStaso and McCorkindale (2011) posit that public relations executives believe social media can transform the ways the public consume news about organizations and their engagement with them. The same executives expressed concern that many practitioners still lacked the ability to effectively employ online communication and cope with a rapidly changing environment. Practitioners complained senior managers often regulate their online activity because they set internal legal controls and ask for pre-approval. Wright and Hinson (2009) found the instantaneous $24 / 7$ nature of social networks and the fact that providing feedback online requires practitioner availability influences the volume of online interactivity for an organization. Consumers expect rapid feedback and view delayed response as indicators of negligence and poor customer service. Trained staff are needed to monitor and respond to comments in a timely manner. Briones et al. (2011) reported practitioners at the American Red Cross complained of a shortage of staff who can respond to feedback 24 hour a day.

\section{Senior management support and encouragement}


In an organization, support and encouragement are defined by employee perception that that their "work organization values their contribution and cares about their well-being" (Zumrah, 2015, p. 78). This is becoming a factor in the work environment for employees who seek "a greater sense of meaning and purpose in their extending working lives" (Cartwright \& Holmes, 2006, p. 200). Tourish and Hargie (2009) argue that the majority of internal communication audits focus on work processes and achievements rather than employees' needs of belonging, satisfaction, loyalty and engagement in an organization. The audits pay attention to issues of the external public and how to reach them, the volume of information received, trust and confidence levels, and customer satisfaction. Ruck and Welch (2012) and Sluss et al. (2008) argue organizational support is a key predictor of levels of productivity and performance among employees. Al-Shohaib et al. (2009) found that organizational encouragement was a predictor of adoption of the Internet for public relations in Saudi Arabia.

Accordingly, it is expected that higher levels of support and encouragement by senior management for public relations and communication practitioners to use social media will predict Instagram posting activities. In addition, support and encouragement of those practitioners' respective departments will predict Instagram posting activities.

Individual-level factors: Perceptions of practitioners and senior managers about Instagram and social media

Valentini (2015) found that perceptions about the Internet and social media in public relations are generally sanguine. Practitioners believe social media will help establish direct dialogue with the public from the spontaneous, direct and interactive nature of online media. Practitioners can circumvent media gatekeepers and filters to reach clients directly, augment market visibility and boost corporate branding and image (DiStaso et al., 2011). Porter et al. 
(2009) found practitioners believe online blogs are important for public relations but felt unprepared to make a full use of them. Lariscy et al. (2009) found that practitioners believe social media are vital to draw attention to issues. Curtis et al. (2010) report practitioners think social media are essential to achieve public relations objectives. Graham and Avery (2013) indicate practitioners think social media could increase dialogue and engagement with their publics on important issues. Practitioners who had positive perceptions and attitudes toward social media were inclined to employ them in their internal and external communication (Moreno et al., 2015).

\section{Research Questions}

Building from the literature review, the following research questions are proposed:

RQ1: What are the public relations functions that banks in Kuwait try to serve using their Instagram accounts?

RQ2: What are the predictors of Instagram posting activity by banks in Kuwait? RQ3: How do predictors of Instagram posting activities of banks in Kuwait relate to public relations and Arab cultural values?

\section{Method}

This research employs mixed research methods to analyze the Instagram use of the 10 national Kuwaiti banks. Two were omitted from analysis because one did not have an Instagram account and the other was not listed in the Kuwait Stock Exchange Market (KSEM) (Table 1). Primary data included a content analysis of posts on banks' Instagram accounts and a survey of the perceptions of 102 public relations/communication practitioners on subjects related to the 
study. A secondary data analysis included information about banks obtained from the website of the KSEM (http://www.boursakuwait.com.kw).

\section{TABLE ONE HERE}

\section{Content analysis, coding sheet and categories}

To determine the function of each post on banks' Instagram accounts, a content analysis was employed. To construct the coding sheet, researchers analyzed the posts of all banks during the first 15 days of the months of January and February of 2016 and documented the functions of different posts. This initial examination helped construct the coding sheet by identifying and categorizing public relations functions, coming to an agreement regarding posts that were

perceived differently, and establishing categories for each post. Later, two research assistants were asked to use the coding sheet separately and analyze posts during the first five days of January 2016 in a pilot study. After they were trained and instructed about the categories and their definitions using a sample of posts, the assistants conducted their pilot study. This study was primarily conducted to ensure the intercoder reliability score of the two assistants would not fall below $0.80(80 \%)$ as an acceptable level. Other purposes were to receive feedback from the assistants on their understanding of the functions of posts, and to clarify any misunderstanding in the coding sheet and definitions of functions. Revisions were made in light of the feedback the coders provided. This pilot study also served as an exercise for the two coders who would later conduct the final content analysis procedure.

For the promotional function, categories of posts included offers, services, and advertisements. The "offers" included those that provided offers, discounts, reduced interest rates for credit cards for certain reasons or during specific times. "Services" included posts promoting bank services, such as opening hours, types of accounts and bank loans information. 
"Advertisements" included posts showing actual print media advertisements or television commercials reposted on Instagram.

The Informational function included five post categories. "News announcements" showed news about the banks' financial standing, history, annual profits, general news or information. These announcements were meant to target the media and the banks' public. "General announcements" captured regular updates or news announcements, mostly of interest to account holders on information about their monthly salaries and student stipends. "Events" included news of information about the banks' events. "Banks' employee news" included news such as employee promotions. Finally, "Banks' image and reputation" subsumed posts about winning awards or messages emphasizing the banks' image, safety, and reputation.

The third function -- "community building" consisted of four categories. "Social responsibility" included posts reflecting the involvement of banks in different social issues. Some examples of such posts include issues of breast cancer, Kuwaiti Independence Day and Mother's Day. "Community engagement" consisted of posts about the banks' actual involvement in community activities and events, usually events sponsored and organized by the bank or involving the bank's participation. "Religious messages" included posts about Islamic occasions, quotations from the Holy Koran, the sayings of Prophet Muhammed and similar messages. "Public information, advice, and instruction" included general information and instructions on various subjects that serve a general interest.

Finally, the "engagement" function consisted of posts encouraging Instagrammers to respond to or interact with the posts. This function included three categories. "Compete to win" included posts encouraging Instagrammers to respond to trivia questions or predict scores of sporting events, with correct answers entered into a lottery for cash prizes. "Mention someone" 
asked Instagrammers to mention people they knew who might like to do an activity or travel to a specific country. Finally, "general engagement" was similar to "compete to win" except it did not result in wining prizes. It asked people either to respond to questions seeking specific answers or provide their opinions about different aspects of life and issues.

\section{Criterion and predictor variables}

The criterion variable this study used was the total number of posts by each bank since starting to use Instagram. Total numbers of posts were obtained from the banks' Instagram profile. For statistical analyses, banks that posted five thousand or more were considered to have a "High" level of posting. Those with anything less were considered "Low." A "High" level of posting was coded as 2 and a "Low" level as 1 (Table 1). This categorization was employed due to the acutely bipolarized distribution of data. There were three sets of predictor variables. The first, market-level predictors, included market value, rate of bank’s share in Kuwait Stock Exchange Market (KSEM), number of branches, and number of Instagram followers. Data for those predictors were obtained from the KSEM's website. Number of Instagram account followers was obtained from the bank's Instagram profile (Table 1).

The second set of predictors, organization-level, consisted of three variables. First was number of employees in each bank, which was obtained from the KSEM's website (Table 1). The other two were culled from the survey to practitioners, which assessed the level of support and encouragement received by public relations/communication practitioners from their senior management to use Instagram and social media, and level of support and encouragement received by the public relations and communication departments from senior management. Individual-level predictors data were obtained from the survey. 


\section{Survey}

Of the 177 communications practitioners approached, 102 completed a survey asking nine questions involving various perceptions. The authors were given access to the available staff at the headquarters of each bank, and a research assistant gave the survey in person to all available practitioners. Of the 75 who did not participate, some were on leave, in meetings or otherwise unavailable. Two survey items assessed organization-level predictors by inquiring about levels of support from senior managers to public relations and communications practitioners to use Instagram and social media. They asked, "What level of support (another item with same wording was used for encouragement) do you receive from your bank's senior management to use social media?" The Cronbach's Alpha reliability score for these items was 0.88. Questions were asked to gauge levels of support and encouragement for public relations and communications departments: "What level of support (another item with same wording was used for encouragement) does your public relations or communications department receive from your bank's senior management?” For these items, responses were located on a scale ranging from 5 as "high level of support (encouragement)" to 0 as "no support (encouragement) at all." The Alpha score was 0.93 .

The individual-level predictors included items examining a trio of perceptions of Instagram and social media. The first asked about individuals' perceptions of using Instagram and social media to achieve public relations objectives. The questions were, "In your opinion, how important are social media (another similar item was used to ask about Instagram) to achieve your bank's public relations purposes?" The Alpha score for the two items was 0.83 . Two other questions asked about the perceptions of senior managers about the importance of social media and Instagram to meet public relations objectives. They were, "In your opinion, 
how important are (is) social media (another similar item was used to ask about Instagram) in achieving public relations objectives for your bank's senior management?" These questions had an Alpha reliability score of 0.84 . Finally, one question asked about the perceptions regarding the importance of Instagram to achieve public relations objectives relative to other options: "In comparison to other social media, how important is Instagram in achieving your bank's public relations objectives?" For all these questions, measurements were scaled from 5 as "extremely important" to 0 as "extremely unimportant."

\section{Results}

The final content analysis used in this study ran for the months of April and May of 2016. Cohen's kappa intercoder reliability revealed the percentage of consistency or agreement for the 1,502 posts was satisfactory $(\kappa=.91,91 \%)$. Final analysis revealed that banks posted on their Instagram accounts primarily for the functions of promotion, information, community building, and engagement.

\section{Instagram use for public relations functions by Kuwaiti banks}

The first research question in this study asks what the public relations functions are for banks in Kuwait that use Instagram. To address this question, a total of 1,502 posts were analyzed. Banks in Kuwait used Instagram for four functions: Promotional posts, $(n=562,37 \%)$, and three comprising public relations $(n=940,63 \%)$, including information dissemination, community building, and interactive engagement. Primarily, Instagram was employed for promotion with 562 (37\%, rank 1) posts, followed by information dissemination 469 (31\%, rank

2) posts, then community building 355 (24\%, rank 3$)$ posts and finally by interactive personal 
engagement posts with 116 (8\%, rank 4). (Table 2). These posts were outliers because they invited communication and comprised the only category related to symmetric communication.

In examining each category, "offers" posts ( $\mathrm{n}=372)$, were the most frequent in the promotion function (66\%) and among all functions (25\%), followed by "services" and "ads" within promotion. "News announcement" represented the most frequent posts $(\mathrm{n}=211,45 \%)$, in the information dissemination function and second (11\%) among all functions after "offers." "General announcement" came second in the information dissemination function, followed by "events," "bank's image and reputation" and finally by “coverage of employees." "Social responsibility" posts ( $\mathrm{n}=120,34 \%)$, came first within community building, followed by "religious message," "public information and advice," and finally by "community engagement." In the Interactive engagement function, "compete to win" posts came first $(n=62,54 \%)$, followed by "general engagement" and "mention someone" (Table 2). As a category, "interactive engagement" symmetrically engaged Instagrammers in posts seeking interactivity comprised 116 posts (8\%, rank 4). The other posts, $1386(92 \%)$, were asymmetrical in nature, primarily by pushing one-way communication and information rather than promoting dialogue or inviting user commentary.

\section{TABLE 2 HERE}

\section{Predictors of Instagram posting activity by Kuwaiti banks}

To explore the level of Instagram posting relative to market-size, independent samples $t$ tests were performed. The results for banks with a greater size in terms of market value $[t(14)=-$ $2.035, p>0.05]$ and rate of share $[t(14)=-1.639, p>0.05]$ were insignificant. However, another $t$-test procedure, which compared banks in terms of number of branches, was significant $[t(14)=-$ 3.032, $p<0.05]$. Banks that had more branches $(M=57, S D=14)$ tended to post more on 
Instagram than banks with fewer branches $(M=33, S D=8)$. Also, the test, comparing level of posts in terms of Instagram followers, indicated a significant difference, $t(14)=-4.480, p<0.05$. Banks with more followers $(M=202,300, S D=77,579)$ posted more on Instagram than banks with fewer followers $(M=28,050, S D=5,719)$. Finally, the $t$-test comparing banks in relation to number of employees was significant, $t(14)=-3.198, p<0.05$. Banks that had more employees $(M=1854, S D=669)$ were more likely to post on Instagram than banks with fewer employees $(M=778, S D=74)$. (Table 3).

\section{TABLE 3 HERE}

Analyses of independent samples of $t$-tests were also conducted to compare posting levels and perceptions of practitioners. Regarding posting level in terms of the perceptions of practitioners and senior managers about the ability of social media and Instagram to achieve public relations objectives, the test was significant, $t(14)=-3.53, p<0.05$. The result indicates practitioners $(M=4.82, S D=0.19)$ and senior management $(M=4.51, S D=0.17)$ who believed social media and Instagram can achieve PR objectives were more likely employed at banks that posted more frequently than those practitioners $(M=4.27, S D=0.24)$ and senior managers $(M=$ 3.63, $S D=0.54)$ employed at banks that posted less. (Table 4).

Practitioners $(M=4.680, S D=0.162)$ who thought Instagram was better than other social media in achieving the bank's PR objectives were more likely in banks that posted more frequently on Instagram, $t(14)=-3.962, p<0.05$, than practitioners $(M=4.01, S D=0.25)$ who thought Instagram was not. (Table 4). Moreover, practitioners $(M=4.38, S D=0.29)$ who received more support and encouragement from senior management were more likely to be in banks that posted more on Instagram, $t(14)=-3.080, p<0.05$, than those who received less support and encouragement $(M=3.51, S D=0.48)$. The test comparing support and 
encouragement of senior managements to departments was not significant, $t(14)=-1.058, p>$ 0.331. (Table 4).

\section{TABLE 4 HERE}

Related to research question two of this study, several predictors of Instagram posting activity were identified. Of all market-level predictors, banks that had more branches and more Instagram followers were more likely to post on Instagram. Banks with more employees were more likely to post on Instagram. Moreover, practitioners and senior managers who thought social media and Instagram could achieve public relations objectives were more likely to serve in banks that posted more on Instagram. Banks that perceived Instagram to be more effective in achieving public relations objectives than other social media predicted a higher number of posts on Instagram. Finally, practitioners who receive more support and encouragement from senior management to use Instagram for public relations posted more on Instagram, while support and encouragement for public relations and communication departments did not increase posting on Instagram. The third research question, which relates predictors of Instagram posting activities with public relations activities of Kuwaiti banks, is addressed in the following discussion to recognize the primacy of culture and religion in Arab countries such as Kuwait.

\section{Discussion}

This study indicates that banks in Kuwait used Instagram for promotion, information dissemination, community building, and interactive engagement. This is analogous with literature from other countries (Lovejoy \& Saxton, 2012; Parveen et al., 2015). Even though Instagram was primarily employed for promotion (37\% of posts), the other public relations functions of Instagram occupied $63 \%$ of posts. The results suggest overemphasis on promotional 
posts underscores the perception of Arab senior management, who generally consider public relations as a form of propaganda (Al-Enad, 1990) meant to persuade and influence public opinion (Badran \& Ayish, 1996; Kirat, 2005). This approach is consistent with undemocratic, top-down and non-Western contexts. Furthermore, the abundant use of Instagram for promotion emphasizes the visual nature of Instagram and its persuasive power for image building, branding, and identity construction (Al-Kandari et al., 2016). Conversely, Facebook is a communitybuilding social medium and Twitter is a text-based, dialogic medium. The composition and characteristics of Instagram as a visual-oriented social medium suggest it is better suited for persuasion, emotional influence and asymmetrical communication models.

The "interactive engagement" function accounted for only $112(8 \%)$ of posts. This outcome mirrors a vast body of research in which the Internet and social media are often used for information dissemination and persuasion (Greenberg \& MacAulay, 2009; Kent et al., 2003; McCorkindale, 2012; Saxton et al., 2007; Valentini, 2015; Waters et al., 2009; Wright \& Hinson, 2011). Research has offered some reasons for this usage that may also apply to the case of Instagram use by Kuwaiti banks. Familiarity with asymmetrical models, unpreparedness for online settings, and lack of knowledge and training to deal with online symmetrical messages prompt practitioners to prefer asymmetrical Instagram posting activities (Wright \& Hinson, 2008; Waters \& Jamal, 2011). In addition, the status of public relations in the Arab world can contribute to this outcome. Arab scholars (Al Enad, 1990; Badran \& Ayish, 1996; Kirat, 2005) argue that Arab public relations models reflect a one-way official communication model of press agentry and information dissemination. Arab managerial and organizational styles, which are characterized as authoritarian, patriarchal, and over-centralized in nature (Kirat, 2005;

Scarborough, 2000) enhance asymmetrical online communication. Such attributes of Arab public 
relations, management and organizations are at odds with normative contexts that embody progressive, innovative, active, independent, spontaneous, and symmetrical public relations and communications.

\section{Predictors of Instagram posting activities}

The results show the majority of market-size, organization, and individual level factors predict the Instagram posting activity of banks, with banks that post more on Instagram more likely to have more branches and Instagram followers. While number of branches and Instagram followers may not directly reflect the number of bank account holders, they are certainly indicators of relative size. Having more branches in different areas in Kuwait can translate to more account holders and need for service in varied areas. Also, the number of Instagram followers can indicate the number of bank account holders. Most of those who follow a bank Instagram account are those who have a bank account and are willing to receive online updates. Hackler and Saxton (2007) found that when an organization grows, it is more likely to receive public attention that requires greater online disclosure. Debreceny et al. (2003) similarly suggest growth is associated with online presence. Having comparatively large Instagram followers requires a bank to post more often to serve different public needs around the clock.

Of organizational factors, number of employees, and support and encouragement from senior managers to use social media and Instagram predicted Instagram posting activity. The outcomes indicate that banks that have more employees are more likely to post on Instagram. Having more employees can equate to a greater number of available staff to maintain and handle different social media accounts. Nah and Saxton (2012) suggested that capacity and resources available to an organization have implications for its social media use. Available staff means a bank can reach and interact with clients and respond to their queries. In addition, professionals 
who received a greater level of support and encouragement from senior management were more likely to post on Instagram. Public relations professional need a nurturing and supportive work environment, which complements the literature showing level of employee satisfaction increases productivity (Chen, Silverthorne, \& Hung, 2006; Tourish \& Hargie, 2009), performance (Ruck \& Welch, 2012) and adoption of the Internet for public relations tasks (Al-Shohaib et al., 2009).

Finally, of all individual-level predictors, practitioners and senior managers who thought social media and Instagram can achieve public relations objectives were more likely to post on Instagram than those who did not. This observation is consistent with Moreno et al. (2015), who found public relations practitioners who had positive perceptions and attitudes toward social media were more inclined to employ them to communicate with internal and external publics. Graham and Avery (2013) found that government officials who perceived social media as effective were more likely to use them in engaging in dialogue with citizens. Also, practitioners who perceived Instagram to be better than other social media in achieving the banks' public relations objectives were more likely to post. This view of Instagram supports the given that Instagram is the most favored social medium by Kuwaiti nationals, followed by Snapchat and Twitter (Greenfield, 2013; Kamal, 2016).

\section{Conclusion}

It is worth noting all of the banks' Instagram posts in this study were in Arabic. When asked about posting in one language only, several communications directors said they use Instagram for Kuwaitis and used Facebook or Twitter to reach non-Kuwaitis because of user preferences. Of import to Instagram as medium is the message content for the banks; 102 of the analyzed posts were religious (Islamic) in nature. Encoding religion into banking is a unique feature of the Instagram use in this study and consistent with Arab culture (Gaither \& Al- 
Kandari, 2014). Roughly half of the banks in Kuwait operate accordingly to Islamic laws and the other half are secular commercial. The authors speculate the inclusion of religious messages that mention by name Allah, Koran and Islam can enhance message credibility and build trust by suggesting the bank operates in accordance and with - and is obedient to - the instructions of Allah.

Such an approach mirrors the Arab cultural value of commitment to religion that distinctly imbues public relations practice in the Middle East (Al-Kandari \& Gaither, 2011). This study positions religion and religious messages within a Western notion public relations as a function of community building (Kruckeberg \& Stark, 1988; Stark \& Kruckeberg, 2001). In the Middle East, the community relates to the collective, and there is scant evidence online platforms can engender the meaningful relationships that permeate Arab culture. This study suggests Instagram is more effective at disseminating information in an Arab context rather than as a means for two-way communication, ostensibly explaining why only $8 \%$ of messages were "interactive engagement" promoting participation in dialogue. A concluding observation is that Instagram by its very nature fosters individualism, which contradicts the Arab cultural value of devotion to the group (Gaither \& Al-Kandari, 2014). Since the focus is on the image, it is more likely to fit branding and information dissemination functions, which were the central use of Instagram by Kuwaiti banks in this study.

This study employed predictors reflecting various levels (market, organization, and individual) to predict Instagram posting activities. Such a holistic approach can provide more information on the adoption of social media and communication technologies for public relations purposes in organizations, and account for a detailed process and determinants that influence adoption (Nah \& Saxton, 2012). Even though most research linking social media to public 
relations reflects a Western, developed country profile, this study confirms that the predictors of Instagram posting activity are similar in nature to those in the West. The study does not suggest, however, that mass communication supplants the Middle Eastern cultural value of personal communication. As Vujnovic \& Kruckeberg (2005) suggest, word-of-mouth, meetings, personal visits and staging speeches have great influence in the Middle East. Rather, the study advances the notion online communication can complement more personalized approaches while embodying Islamic ideals and glorifying Allah.

Future research could compare the use of Facebook as a community-building social medium, Twitter as a mainly text-based social medium, and Instagram as a mainly visual-based social medium, to see how social media are used for varying public relations functions. It could also compare the use of social media by different organizational types representing for-profit private and public non-for-profit sectors. More research is also needed to decenter Western social media and consider social media usage in countries with nation-specific platforms such as Weibo in China to reflect the richness of global public relations practices and guide theory development and test existing theories in the digital age. 


\section{Table 1}

\section{Banks' secondary data employed in statistical analyses}

\begin{tabular}{|l|c|c|c|c|c|c|c|}
\hline Bank & $\begin{array}{c}\text { Total \# of } \\
\text { Instagram } \\
\text { posts till } \\
\text { May } \\
2016^{*}\end{array}$ & $\begin{array}{c}\text { Categories } \\
\text { of total \# } \\
\text { of } \\
\text { Instagram } \\
\text { posts }\end{array}$ & $\begin{array}{c}\text { Market } \\
\text { value }\end{array}$ & $\begin{array}{c}\text { Rate of } \\
\text { bank's } \\
\text { share in } \\
\text { the stock } \\
\text { market** }\end{array}$ & $\begin{array}{c}\text { \# of } \\
\text { branches }\end{array}$ & $\begin{array}{c}\text { \# of } \\
\text { Employees }\end{array}$ & $\begin{array}{c}\text { \# of } \\
\text { Instagram } \\
\text { followers }\end{array}$ \\
\hline $\begin{array}{l}\text { Boubyan } \\
\text { Bank }\end{array}$ & 5,772 & High & 939.466 & 411 & 37 & 1096 & 234,000 \\
\hline $\begin{array}{l}\text { National } \\
\text { bank of } \\
\text { Kuwait }\end{array}$ & 5,763 & High & $4,142.21$ & 700 & 69 & 2271 & 282,000 \\
\hline $\begin{array}{l}\text { Kuwait } \\
\text { Finance } \\
\text { House }\end{array}$ & 5,093 & High & $3,090.41$ & 537 & 65 & 2541 & 194,000 \\
\hline Gulf Bank & 5,031 & High & 743.743 & 244 & 58 & 1506 & 99,200 \\
\hline $\begin{array}{l}\text { Commercial } \\
\text { Bank }\end{array}$ & 2,799 & Low & 576.215 & 345 & 44 & 868 & 26,800 \\
\hline $\begin{array}{l}\text { Ahli Bank of } \\
\text { Kuwait }\end{array}$ & 2,409 & Low & 516.514 & 313 & 31 & 806 & 33,100 \\
\hline $\begin{array}{l}\text { Kuwait } \\
\text { International } \\
\text { Bank }\end{array}$ & 1,980 & Low & 253.108 & 214 & 28 & 703 & 31,800 \\
\hline Burgan Bank & 645 & Low & 757.443 & 353 & 28 & 734 & 20,500 \\
\hline
\end{tabular}

*A Kuwaiti Dinar is equivalent to 3 US dollars. **300 Fills is equivalent to 1 US dollars.

Table 2

Instagram use for public relations functions in Kuwait $(N=1502)$

\begin{tabular}{|l|l|l|l|l|l|}
\hline Posts' functions & $\begin{array}{l}\text { Frequency } \\
\text { of posts }\end{array}$ & $\begin{array}{l}\text { Percentage } \\
\text { of posts } \\
\text { within a } \\
\text { function } \\
\text { category }\end{array}$ & $\begin{array}{l}\text { Rank of } \\
\text { posts within } \\
\text { a function } \\
\text { category }\end{array}$ & $\begin{array}{l}\text { Percentage of } \\
\text { posts with all } \\
\text { functions }\end{array}$ & $\begin{array}{l}\text { Rank in } \\
\text { comparison to } \\
\text { all other } \\
\text { function } \\
\text { categories }\end{array}$ \\
\hline Promotion (\# of posts = 562; percentage of posts $\mathbf{3 7 \%}$, rank of function = 1) & $25 \%$ & 1 \\
\hline Offers & 372 & $66 \%$ & 1 & $11 \%$ & 3 \\
\hline Services & 168 & $30 \%$ & 2 & $1 \%$ & 15 \\
\hline Ads & 22 & $4 \%$ & 3 & $13 \%$ & 2 \\
\hline Information dissemination (\# of posts $=\mathbf{4 6 9} ;$ percentage of posts = 31\%, rank of function = 2) \\
\hline News announcements & 211 & $\mathbf{4 5 \%}$ & 1 & $2 \%$ & 4 \\
\hline General announcements & 128 & $27 \%$ & 2 & $9 \%$ \\
\hline
\end{tabular}




\begin{tabular}{|l|l|l|l|l|l|}
\hline Events & 62 & $13 \%$ & 3 & $4 \%$ & 9 \\
\hline Bank's image and reputation & 43 & $9 \%$ & 4 & $3 \%$ & 11 \\
\hline Coverage of employees & 25 & $6 \%$ & 5 & $2 \%$ & 14 \\
\hline Community building (\# of posts & $\mathbf{3 5 5}$; percentage of posts = 24\%, rank of function = 3) \\
\hline Social responsibility & 120 & $34 \%$ & 1 & $8 \%$ & 5 \\
\hline Religious message & 102 & $29 \%$ & 2 & $7 \%$ & 6 \\
\hline Public information and advice & 86 & $24 \%$ & 3 & $6 \%$ & 7 \\
\hline Community engagement & 47 & $13 \%$ & 4 & $3 \%$ & 11 \\
\hline Interactive engagement (\# of posts & $\mathbf{1 1 6}$ percentage of posts = 8\%, rank of function = 4) \\
\hline Compete to win & 62 & $54 \%$ & 1 & $4 \%$ & 9 \\
\hline General engagement & 27 & $23 \%$ & 3 & $2 \%$ & 14 \\
\hline Mention someone & 27 & $23 \%$ & 3 & $2 \%$ & 14 \\
\hline
\end{tabular}

Table 3

Comparison t-tests between high/low Instagram posting by banks

\begin{tabular}{|c|c|c|c|c|c|c|c|}
\hline Predictors & $\begin{array}{c}\text { Instagram } \\
\text { posts }\end{array}$ & $\begin{array}{c}\mathrm{N} \text { of } \\
\text { banks }\end{array}$ & Mean & $\begin{array}{c}\text { Std. } \\
\text { Deviation }\end{array}$ & $\begin{array}{c}\text { Std. Error } \\
\text { Mean }\end{array}$ & $\begin{array}{c}\mathrm{t}- \\
\text { score }\end{array}$ & $\begin{array}{c}\mathrm{P}- \\
\text { Value }\end{array}$ \\
\hline \multirow{2}{*}{ Market value } & Low & 4 & 525.82 & 208.68 & 104.34 & \multirow[b]{2}{*}{-2.035} & \multirow[b]{2}{*}{0.088} \\
\hline & High & 4 & $2,228.96$ & $1,660.45$ & 830.23 & & \\
\hline \multirow{2}{*}{$\begin{array}{l}\text { Rate of share in } \\
\text { KSEM }\end{array}$} & Low & 4 & 306.25 & 63.88 & 31.94 & \multirow{2}{*}{-1.639} & \multirow{2}{*}{0.152} \\
\hline & High & 4 & 473 & 193.14 & 96.57 & & \\
\hline \multirow{2}{*}{ \# of branches } & Low & 4 & 32.75 & 7.63 & 3.82 & \multirow{2}{*}{-3.032} & \multirow{2}{*}{0.023} \\
\hline & High & 4 & 57.25 & 14.24 & 7.12 & & \\
\hline \multirow{2}{*}{$\begin{array}{l}\text { \# of Instagram } \\
\text { followers }\end{array}$} & Low & 4 & 28,050 & $5,719.27$ & 2859.63 & \multirow{2}{*}{-4.480} & \multirow{2}{*}{0.004} \\
\hline & High & 4 & 202,300 & $77,578.95$ & 38789.47 & & \\
\hline \multirow{2}{*}{ \# of employees } & Low & 4 & 777.75 & 74.04 & 37.02 & \multirow{2}{*}{-3.198} & \multirow{2}{*}{0.019} \\
\hline & High & 4 & 1853.5 & 668.71 & 334.36 & & \\
\hline
\end{tabular}

Table 4

Comparison t-tests indicating to significant differences on levels of posting (High/Low) according to survey measurements

\begin{tabular}{|c|c|c|c|c|c|c|c|}
\hline Perceptions & \begin{tabular}{|l} 
Instagram \\
posts
\end{tabular} & $\mathrm{N}$ & Mean & $\begin{array}{c}\text { Std. } \\
\text { Deviation }\end{array}$ & $\begin{array}{l}\text { Std. } \\
\text { Error } \\
\text { Mean }\end{array}$ & $\begin{array}{c}\mathrm{t}- \\
\text { score }\end{array}$ & $\begin{array}{c}\text { P- } \\
\text { Value }\end{array}$ \\
\hline \multirow{2}{*}{$\begin{array}{l}\text { Individuals perceptions about } \\
\text { social media and Instagram to } \\
\text { achieve PR objectives }\end{array}$} & Low & 4 & 4.273 & 0.241 & 0.121 & \multirow{2}{*}{$\begin{array}{c}- \\
3.535\end{array}$} & \multirow[t]{2}{*}{0.012} \\
\hline & High & 4 & 4.820 & 0.194 & 0.097 & & \\
\hline \multirow{2}{*}{$\begin{array}{l}\text { Senior managements perceptions } \\
\text { about social media and } \\
\text { Instagram to achieve PR } \\
\text { objectives }\end{array}$} & Low & 4 & 3.628 & 0.539 & 0.269 & \multirow{2}{*}{$\begin{array}{c}- \\
3.136\end{array}$} & \multirow[t]{2}{*}{0.020} \\
\hline & High & 4 & 4.513 & 0.168 & 0.084 & & \\
\hline
\end{tabular}




\begin{tabular}{|l|l|l|l|l|l|l|l|}
\hline Comparing Instagram to other & Low & 4 & 4.093 & 0.249 & 0.124 & - & 0.007 \\
\cline { 2 - 7 } $\begin{array}{l}\text { social media in achieving PR } \\
\text { objectives }\end{array}$ & High & 4 & 4.680 & 0.162 & 0.081 & 3.962 & \\
\hline $\begin{array}{l}\text { Senior managements support and } \\
\text { encouragement for using social } \\
\text { media and Instagram }\end{array}$ & Low & 4 & 3.513 & 0.478 & 0.239 & - & 0.022 \\
\cline { 2 - 8 } & High & 4 & 4.375 & 0.291 & 0.146 & 3.080 & \\
\hline $\begin{array}{l}\text { Senior management support and } \\
\text { encouragement for departments }\end{array}$ & Low & 4 & 3.945 & 0.519 & 0.260 & - & 0.331 \\
\cline { 2 - 7 } & High & 4 & 4.275 & 0.346 & 0.173 & 1.058 & \\
\hline
\end{tabular}

\section{References}

Adams, A., \& McCorkindale, T. (2013). Dialogue and transparency: A content analysis of how the 2012 presidential candidates used twitter. Public Relations Review, 39(4), 357-359.

Al-Kandari, A. A., \& Gaither, T. K. (2011). Arabs, the West and public relations: A critical/cultural study of Arab cultural values. Public Relations Review, (37)3, 266-273.

Al-Kandari, A.A., Melkote, S.R., \& Sharif, A. (2016). Needs and motives of Instagram users that predict self-disclosure use: A case study of young adults in Kuwait. Journal of Creative Communications, (11)2, pp. 85-101.

Al-Enad, A.H. (1990). Public relations roles in developing countries. Public Relations Quarterly, 35(1), pp. 24-26.

Alikilic, O., \& Atabek, U. (2012). Social media adoption among Turkish public relations professionals: A survey of practitioners. Public Relations Review, 38(1), pp. 56-63.

Al-Shohaib, K., Frederick, E., Al-Kandari, A.A.J., \& Dorsher, M.D. (2009). Factors influencing the adoption of the internet by public relations professionals in the private and public sectors of Saudi Arabia. Management Communication Quarterly, (24)1, pp. 104-121.

Al-Tarah, K. (1995). Dawer at elaqat at umah wal clam fee muasasat al Estethmar [The role of public relations and the media in investment institutions]. In Kuwait University's First Public Relations Conference, Kuwait City.

Allaguia, I., \& Breslowba, H. (2016). Social media for public relations: Lessons from four effective cases. Public Relations Review, 42(1), 20-30.

Ayish, M., \& Awad, A. (1994). Public relations: An Islamic perspective. Unpublished paper, Faculty of Humanities and Social Sciences, United Arab Emirates University.

Ayish, M., \& Kruckeberg, D. (1999). Abu Dhabi National Oil Company (ADNOC). Fifteen case studies in international public relations. The Institute for Public Relations. 
Badran, A. (1994). Public relations in the United Arab Emirates. Paper presented at the annual conference of the International Communication Association, Sydney, Australia.

Badran, A. B., \& Ayish, M. I. (1996, December 17). Manager and technician roles of public relations practitioners in public and private organizations in the United Arab Emirates: an exploratory study. Paper presented at the conference on Strategic Planning in Public Relations, Department of Mass Communication, Faculty of Humanities and Social Sciences, United Arab Emirates University, Al-Ain, UAE.

Barnes, N.G., Lescault, A.M. \& Andonian, J. (2012). Social media surge by the 2012 Fortune 500: increase use of blogs, Facebook, Twitter and more. Charlton College of Business Center for Marketing Research, University of Massachusetts Dartmouth, North Dartmouth, MA. Retrieved November 11, 2012, from www.umassd.edu/cmr/socialmedia/2012fortune500/

Bergström, T., \& Bäckman, L. (2013). How the utilization of Instagram builds and maintains customer relationships. A Thesis. Retrieved June 20, 2018, from from: http://su.divaportal.org/smash/record.jsf?pid=diva2\%3A625012\&dswid=4073

Breakenridge, D. (2012). Social Media and Public Relations: Eight new practices for the PR professional. London, England: Pearson Education.

Briones, R.L., Kuch, B., Liu, B.F., \& Jin, Y. (2011). Keeping up with the digital age: How the American Red Cross uses social media to build relationships. Public Relations Review, 37(1), pp.37-43.

Cartwright, S., \& Holmes, N. (2006). The meaning of work: The challenge of regaining employee engagement and reducing cynicism. Human Resource Management Review, 16(2), 199-208.

Cho, M., Schweickart, T., \& Haase, A. (2014). Public engagement with nonprofit organizations on Facebook. Public Relations Review, 40(3), 565-567.

CIA Factbook. (2017). Kuwait. Retrieved July 20, 2018, from https://www.cia.gov/ library/publications/the-world-factbook/geos/ku.html

Conner, C. (2016). The new era of media: Visual public relations. Forbes. Retrieved July 25, 2018, from https://www.forbes.com/sites/cherylsnappconner/2016/10/28/the-new-era-of-mediavisual-public-relations/\#15b6586b5427

Curtis, L., Edwards, C., Fraser, K., Gudelsky, S., Holmquist, J., Thornton, K., \& Sweetster, K.D. (2010). Adoption of Social Media for public relations by nonprofit organizations. Public Relations Review, 36, 90-92.

Craven, B.M., \& Marston, C.L. (1999). Financial reporting on the Internet by leading UK companies. European Accounting Review, 8(2), pp. 321-333. 
Debreceny, R., Gray, G.L., \& Rahman, A. (2003). The determinants of Internet financial reporting. Journal of Accounting and Public Policy, 21(4), pp. 371-394.

DiStaso, M.W., McCorkindale, T., \& Wright, D.K. (2011). How public relations executives perceive and measure the impact of social media in their organizations. Public Relations Review, 37(3), pp. 325-328.

Einwiller, S. A., \& Steilen, S. (2015). Handling complaints on social network sites-An analysis of complaints and complaint responses on Facebook and Twitter pages of large US companies. Public Relations Review, 41(2), 195-204.

Al-Kandari, A. A., \& Gaither, T. K. (2011). Arabs, the West and public relations:

A critical/cultural study of Arab cultural values." Public Relations Review, (37)3, 266-273.

Gaither, T. K., \& Al-Kandari, A. A. (2014). The cultural-economic model and public relations in the Middle East: An examination of the Islamic banking system in Kuwait. Public Relations Review, (40)1, pp. 33-41.

Graham, M., \& Avery, E. (2013). Government public relations and social media: An analysis of the perceptions and trends of social media use at the local government level. Public Relations Journal, 7(4), pp. 1-21.

Greenberg, J., \& MacAulay, M. (2009). NPO 2.0? Exploring the web presence of environmental nonprofit organizations in Canada. Global Media Journal, 2(1), p. 63-71.

Greenfield, R. (2013). In Kuwait, Instagram accounts are big business. The Wire. Retrieved July 22, 2018, from http://www.thewire.com/technology/2013/07/kuwait-instagram-accounts-are-bigbusiness/67127/

Hackler, D., \& Saxton, G.D. (2007). The strategic use of information technology by nonprofit organizations: Increasing capacity and untapped potential. Public Administration Review, 67(3), pp. 474-487.

Instagram. (2017). Instagram. Retrieved July 25, 2018, https://www.instagram.com/

Jackson, D. (2015a). Twitter vs. Instagram: Which is best for your brand? Retrieved January 23, 2018, from http://sproutsocial.com/insights/twitter-vs-instagram/

Jackson, D. (2015b). Instagram vs Facebook: Which is best for your brand? Retrieved February 3, 2018, from http://sproutsocial.com/insights/instagram-vs-facebook/

Kamal, S. (2016). Social media usage in Kuwait. A report by Kuwait News Agency. Retrieved November 17, 2017, from http://www.kuna.net.kw/ArticlePrintPage.aspx?id =2514275\& language $=\mathrm{en}$ 
Kelleher, T. (2009). Conversational voice, communicated commitment, and public relations outcomes in interactive online communication. Journal of communication, 59(1), pp. 172-188.

Kent, M. L., \& Taylor, M. (1998). Building dialogic relationships through the World Wide Web. Public Relations Review, 24(3), pp. 321-334.

Kent, M.L., Taylor, M., \& White, W.J. (2003). The relationship between Web site design and organizational responsiveness to stakeholders. Public relations review, 29(1), pp. 63-77.

Kirat, M. (2005). Public relations practice in the Arab World: A critical assessment. Public Relations Review, 31(3), pp. 323-332.

Kirat, M. (2006). Public relations in the United Arab Emirates: The emergence of a profession. Public Relations Review, 32(3), pp. 254-260.

Kruckeberg, D. (1996). A global perspective on public relations ethics: The Middle East. Public Relations Review, 22(2), 181-190.

Kruckeberg, D., \& Stark, K. (1988). Public Relations and community: A reconstituted theory. New York: Praeger.

Lariscy, R., Avery, E., Sweetster, K., \& Howes, P. (2009). Monitoring public opinion in cyberspace. Public Relations Journal, 3(4). Retrieved from http://www.prsa.org/SearchResults/download/6D030406/0/Monitoring_Public_Opinion_in_Cyberspace_How_Corpor

Lee, A. M., Gil de Zúñiga, H., Coleman, R., \& Johnson, T. J. (2014). The dialogic potential of social media: Assessing the ethical reasoning of companies' public relations on Facebook and Twitter. Ethical practice of social media in public relations. New York, NY: Routledge.

Lovejoy, K., Waters, R.D., \& Saxton, G.D. (2012). Engaging stakeholders through Twitter: How nonprofit organizations are getting more out of 140 characters or less. Public Relations Review, 38(2), pp. 313-318.

Lovejoy, K., \& Saxton, G.D. (2012). Information, community, and action: How nonprofit organizations use social media. Journal of Computer-Mediated Communication, 17(3), pp. 337353.

McCorkindale, T. (2010). Can you see the writing on my wall? A content analysis of the Fortune 50's Facebook social networking sites. Public Relations Journal, 4(3), pp. 1-13.

McCorkindale, T. (2012). Follow me or be my friend: How organizations are using Twitter and Facebook to build relationships and to communicate transparently and authentically. New media in public relations, 3 , pp. 67-74. 
Moreno, A., Navarro, C., Tench, R., \& Zerfass, A. (2015). Does social media usage matter? An analysis of online practices and digital media perceptions of communication practitioners in Europe. Public Relations Review, 41(2), pp. 242-253.

Nah, S., \& Saxton, G.D. (2012). Modelling the adoption and use of social media by nonprofit organizations. New Media \& Society, p.1461444812452411. Retrieved October 30, 2017, from http://nms.sagepub.com/content/early/2012/08/07/1461444812452411.abstract

Oyelere, P., Laswad, F., \& Fisher, R. (2003). Determinants of internet financial reporting by New Zealand companies. Journal of International Financial Management \& Accounting, 14(1), pp. 26-63.

Pew Social Media Report. (2015). Mobile Messaging and Social Media 2015. Retrieved October 17, 2017, from http://www.pewinternet.org/

Pew Social Media Report. (2016). Social Media Update 2016. Retrieved October 17, 2017, from http://www.pewinternet.org/

Pew Social Media Report. (2018). Social Media Use in 2018. Retrieved October 20, 2017, from http://www.pewinternet.org/

Porter, L., Sweetser, K., \& Chung, D. (2009). The blogosphere and public relations: Investigating practitioners' roles and blog use. Journal of Communication Management, 13(3), pp. 250-267.

Pressgrove, G., Janoske, M., \& Haught, M. J. (2018). Editors' letter: New research and opportunities in public relations and visual communication. Public Relations Review, 44, pp. 317-320.

Ruck, K., \& Welch, M. (2012). Valuing internal communication; management and employee perspectives. Public Relations Review, 38(2), pp. 294-302.

Saffer, A. J., Sommerfeldt, E. J., \& Taylor, M. (2013). The effects of organizational Twitter interactivity on organization-public relationships. Public Relations Review, 39(3), 213-215.

Saxton, G.D., Guo, S.C., \& Brown, W.A. (2007). New dimensions of nonprofit responsiveness: The application and promise of Internet-based technologies. Public performance \& management review, 31(2), pp. 144-173.

Saxton, G.D., \& Waters, R.D. (2014). What do stakeholders like on Facebook? Examining public reactions to nonprofit organizations' informational, promotional, and community-building messages. Journal of Public Relations Research, 26(3), pp. 280-299.

Scarborough, J. (2000). The origins of cultural differences and their impact on management. Greenwood Publishing Group. 
Sluss, D., Klimchak, M., \& Holmes, J. (2008). Perceived organisational support as a mediator between relational exchange and organisational identification. Journal of Vocational Behaviour, 73(3), pp. 457-464.

Sriramesh, K. (1996). Power distance and public relations: An ethnographic study of southern Indian organizations. In Culbertson, H. M., (Ed.) International public relations: A comparative analysis (p. 171-190). Mahwah, NJ: Lawrence Erlbaum.

Stark, K., \& Kruckeberg, D. (2001). Public relations and community: a reconstructed theory revisited. In R. Heath (Ed.), The Handbook of public relations (pp. 51-59). Thousand Oaks, CA: Sage.

Statista (2016). Number of Instagram users in the Middle East and North Africa in 2016. Retrieved January 18, 2019, from https://www.statista.com/statistics/730042/mena-number-ofinstagram-user-by-country/

Statista (2018, October). Leading countries based on number of Instagram users as of October 2018 (in millions). Retrieved January 18, 2019, from https://www.statista.com/statistics/ 578364/countries-with-most-instagram-users/

Tourish, D., \& Hargie, O. (2009). Communication and organisational success. In O. Hargie, \& D. Tourish (Eds.), Auditing organisational communication (pp. 3-26). London, England: Routledge.

Valentini, C. (2015). Is using social media "good" for the public relations profession? A critical reflection. Public Relations Review, 41(2), pp. 170-177.

Waters, R.D., Burnett, E., Lamm, A., \& Lucas, J. (2009). Engaging stakeholders through social networking: How nonprofit organizations are using Facebook. Public relations review, 35(2), pp. 102-106.

Waters, R.D., \& Jamal, J.Y. (2011). Tweet, tweet, tweet: A content analysis of nonprofit organizations' Twitter updates. Public Relations Review, 37(3), pp. 321-324.

Weberling, B., Waters, R.D., \& Tindall, N.T.J. (2012). The role of text messaging in public relations: Testing the situational theory of publics for mobile giving campaigns. New media and public relations (2nd ed., pp. 189-197). New York, NY: Peter Lang.

Wright, D.K., \& Hinson, M.D. (2008). How blogs and social media are changing public relations and the way it is practiced. Public relations journal, 2(2), pp.1-21.

Wright, D.K., \& Hinson, M.D. (2009, March). An analysis of the increasing impact of social and other new media on public relations practice. Paper presented at the 12th annual International Public Relations Research Conference, Miami, Florida. 
Wright, D.K., \& Hinson, M.D. (2011). A three-year longitudinal analysis of social and emerging media use in public relations practice. Public Relations Journal, 5(3), pp.1-32.

Wright, D.K., \& Hinson, M.D. (2013). An updated examination of social and emerging media use in public relations practice: A longitudinal analysis between 2006 and 2014. Public Relations Journal, 7(3), pp.1-39.

Zumrah, A. R. (2015). Training, job satisfaction, POS and service quality: The case of Malaysia. World, 6(2), 74-91. 